\title{
Temporal Variations in the Distribution of Interstitial Meiofauna along the Southwest Coast of India
}

\section{Anila Kumary $\mathbf{K S}^{*}$}

Kuriakose Gregorios College, Pampady, Kottayam, Kerala, India

"Corresponding author: Anila Kumary KS, Kuriakose Gregorios College, Pampady, Kottayam, Kerala, India, Tel: 09000633008; E-mail: ksanilakumary@yahoo.co.in

Received date: Oct 27, 2016; Accepted date: Nov 15, 2016; Published date: Nov 18, 2016

Copyright: (c) 2016 Anila Kumary KS. This is an open-access article distributed under the terms of the Creative Commons Attribution License, which permits unrestricted use, distribution, and reproduction in any medium, provided the original author and source are credited.

\begin{abstract}
The present paper depicts the dynamics of meiobenthic assemblages in relation to environmental variables along the coast of Thiruvananthapuram, Kerala on the southwest coast of India. Meiobenthic community consisted of 11 taxa in which nematodes, foraminifers and copepods dominated. Considerable temporal variations are identifiable for all meiofaunal taxa. The ambient physico-chemical conditions of water and physical changes in sediment are responsible for the temporal distribution of meiobenthos. Vertically a downward migration of meiofauna has been observed in the sand column due to better drainage, high atmospheric temperature and exposure.
\end{abstract}

Keywords: Meiofauna; Seasonal variation; South west coast of India; Macrofauna

\section{Introduction}

Studies on benthic populations have been widely accepted as a tool for assessing the health of the environment because of certain unique qualities displayed by benthic invertebrates. Being an important link in the food chain between bacteria and macrofauna of sediments, meiofauna populations are probably suitable indicators of the benthic ecosystem balance. High sensitivity, rapid turnover rate, quick response, life cycles entirely spent in sediments and relative pollution stability makes meiofauna a valid tool to assess the impact of environmental stress. Monitoring of coastal environment is one of the key tools in scientific management of coastal resources.

Studies on interstitial meiobenthic assemblages in relation to environmental variables from the Indian beaches are scanty. Initial meiobenthic studies reported from the Indian coast were from the mud bank region of Kerala coast [1]. Following those a few more studies on the distribution and abundance of meiobenthos have been made off the Indian coast [2-8]. Thiruvananthapuram, the capital district of Kerala on the southwest coast of India, is the southernmost district of the state. Considering the role of meiobenthos as key indicators of environmental stress, the present paper explores the distribution of meiobenthos and its temporal variation in Thiruvananthapuram coast of Kerala in relation to the prevailing environmental parameters as structuring factors of interstitial meiofauna in the sandy beaches.

\section{Materials and Methods}

The study was carried out along the Thiruvanandapuram coast of Kerala at two selected beaches, station I, located at Poonthura coast and station II, at Adimalathura coast, lying between latitudes 8020'-8030; North and longitudes 76055'-77003' east. Samples were taken monthly from the 2 stations up to a depth of $25 \mathrm{~cm}$ using a graduated steel cover having a length of $25 \mathrm{~cm}$ and diameter $5.5 \mathrm{~cm}$. The sediment core was then divided into $5 \mathrm{~cm}$ and each segment was immediately removed intact into separate polythene bags. The samples were anaesthetized with $7 \% \mathrm{MgCl}$ and preserved in $4 \%$ buffered formalin $0.1 \%$ Rose Bengal was added to the sample for efficient extraction of the fauna and was separated by suspension decantation method [9]. Separated benthic sample were then processed through a set of two sieves with $500 \mathrm{~mm}$ and $42 \mathrm{~mm}$ mesh sizes for the separation of meiofauna. Meiobenthos was then counted on a higher taxonomic level using a binocular microscope.

Observations of physic-chemical characteristic of sea water were made according to standard methods $[10,11]$. Bottom sediment was subjected to the analysis of geochemical variables temperature, $\mathrm{pH}$, organic carbon and texture [12]. Monthly values of all parameters analysed were pooled to obtain the seasonal values as pre monsoon (Feb-May), monsoon (June-Sep) and post monsoon (Oct-Jan).

\section{Results and Discussion}

The interstices of sandy beaches are profusely inhabited by meiobenthic invertebrates which are of great ecological significance. The taxonomic composition, density and distribution of meiobenthic fauna vary considerably from space to space depending on a wide variety of factors. Exposure, predation, competition, grain size, organic matter and oxygen largely determine the distribution of meiofauna in Indian beaches [13]. Numerically meiobenthic abundance varied slightly in the two beaches. The overall density variation was from 1288 to $8386 / 100 \mathrm{~cm}^{2}$ at the Poonthura coast and from 1151 to $10795 / 100$ $\mathrm{cm}^{2}$ at the Adimalathura coast (Table 1).

Faunal composition of meiobenthos obtained from the two sandy beaches of Thiruvananthapuram coast consisted of 11 taxa coprising foraminifera, Turbellaria, Kinorhyncha, Nematoda, oligochaeta, Polychaeta, Archiannelida, Ostracoda, Copepoda, Amphipoda and Arachnida. Over all abundance of meiobenthos has been in the order Nematoda, Copepoda, Foraminifera, Oligochaeta and Ostracoda at the Poonthura coast and in the order Nematoda, Foraminifera, Copepoda, Archiannelida and Oligochaeta at the Adimalathura coast (Figure 1). In general nematodes dominated the meiobenthic community of Thiruvananthapuram coast. Nematodes are the most abundant 
Page 2 of 4

meiofaunal community of Indian beaches which often represents more than $80 \%$ of benthic meiofauna $[5,14-18]$.

\begin{tabular}{|l|l|l|}
\hline Season & Poonthura coast & Adimalathura coast \\
\hline \multirow{3}{*}{ Pre monsoon } & Range 3465-6073 & Range 2579-4631 \\
\cline { 2 - 3 } & Mean 4945 & Mean 3592 \\
\hline \multirow{2}{*}{ Monsoon } & Range 1288-4590 & Range 1511-5677 \\
\cline { 2 - 3 } & Mean 2511 & Mean 2508 \\
\hline \multirow{2}{*}{ Post monsoon } & Range 1559-8386 & Range 4540-10795 \\
\cline { 2 - 3 } & Mean 6617 & Mean 7884 \\
\hline
\end{tabular}

Table 1: Temporal variations $\left(\mathrm{No} / 100 \mathrm{~cm}^{2}\right)$ in meiofaunal density along Thiruvananthapuram coast, Kerala.

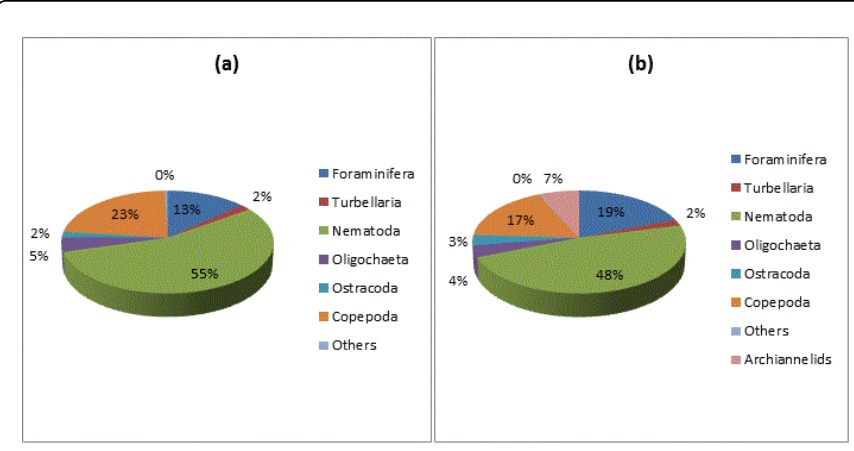

Figure 1: Composition of meiofauna along Thiruvananthapuram (aPoonthura, b-Adimalathura) coast.

The study revealed distinct temporal variation in the interstitial meiofaunal components along the coast of Thiruvananthapuram (Figure 2). Faunal abundance was higher during the post monsoon period followed by pre monsoon. A distinct feature of the Indian beaches is the influence of monsoon rains that adversely affect the density of the fauna. During the monsoon period (June-Sept) the beach configuration changes drastically at short term intervals due to severe erosion or heavy deposition. Strong wave action during the monsoon has the capacity to completely remove or deposit the substratum. During the high turbulence period sediment particles get rearranged affecting the interstitial spaces and the living space available for the organisms that get shifted continuously. This phenomenon might uproot the benthic fauna and expose them to the risk of predation $[19,20]$.

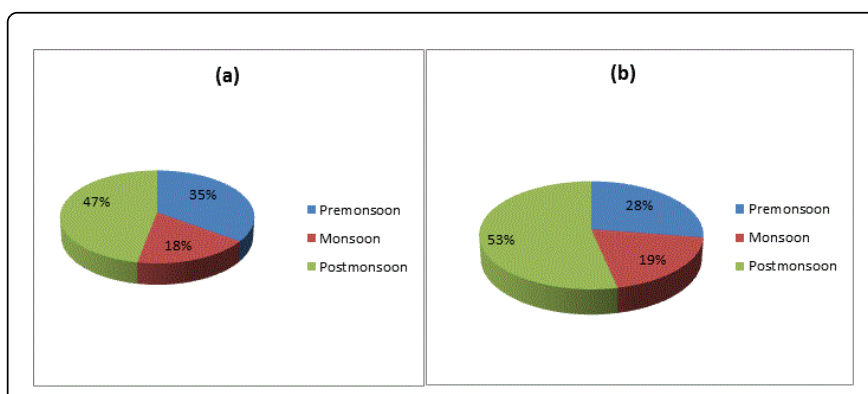

Figure 2: Seasonal variations in the distribution of meiofauna along Thiruvananthapuram (a-Poonthura, b-Adimalathura) coast.

The ambient physico-chemical conditions and the physical change in the sediments are responsible for the temporal distribution of meiofauna. There were considerable fluctuations in the density of all taxa from month to month. Increased temperature, high salinity, stable beach conditions and the probable greater food availability favored the rich post and pre monsoon populations. Seasonal variations in hydrobiological and geological variables are presented in Tables 2 and 3 respectively. The periods of high density of interstitial meiobenthic community in the present study is coincided with increased water and sediment temperature, $\mathrm{pH}$, dissolved oxygen and increased organic carbon in the sediment together with higher proportion of silt and clay. Seasonal breeding is characteristic of meiofauna [21] and the increased meiobenthic density is coinciding with intense breeding activities of meiofauna during the high temperature period $[22,23]$. Temperature may also influence population increase indirectly by controlling supply of bacterial and diatom food. Size of sand grains was reported to be a major factor influencing meiofaunal abundance [5,13,24-27]. Interstitial fauna develop best in sands with medium diameter [9] and moderate organic enrichment [21]. Sandy beaches of Kerala in general have extremely low organic matter in sediment. Faunal abundance was higher during the post and pre monsoon months (Figure 2) with nematodes recording maximum abundance followed by copepods in the Poontura beach and foraminifers at the Adimalathura beach. On average nematode contributed $57.96 \%$ (pre-monsoon), $47.4 \%$ (monsoon) and 49.25\% (post monsoon) of the total meiobenthic fauna. Prevalence of nematode fauna in meiofaunal community of Indian beaches was reported earlier [15,16,28]. Abundance of foraminifera in sandy substrata was also reported from Indian beaches $[1,15]$.

\begin{tabular}{|c|c|c|c|c|c|c|}
\hline \multirow{2}{*}{ Variable } & \multicolumn{3}{|c|}{ Poonthura coast } & \multicolumn{3}{|c|}{ Adimalathura coast } \\
\hline & Pre monsoon & Monsoon & Post monsoon & Pre monsoon & Monsoon & Post monsoon \\
\hline Temperature $\left({ }^{\circ} \mathrm{C}\right)$ & $30.30 \pm 0.337$ & $24.10 \pm 0.447$ & $28.20 \pm 0.561$ & $29.80 \pm 0.719$ & $23.80 \pm 0.137$ & $28.40 \pm 0.666$ \\
\hline $\mathrm{pH}$ & $8.21 \pm 0.088$ & $7.642 \pm 0.026$ & $7.91 \pm 0.018$ & $8.21 \pm 0.031$ & $7.54 \pm 0.073$ & $8.14 \pm 0.003$ \\
\hline Salinity (S.10-3) & $33.88 \pm 0.113$ & $32.14 \pm 0.831$ & $32.21 \pm 0.192$ & $34.24 \pm 055$ & $32.18 \pm 0.512$ & $33.90 \pm 0.522$ \\
\hline Dissolved oxygen $(\mathrm{ml} / \mathrm{l})$ & $5.64 \pm 0.696$ & $4.32 \pm 0.768$ & $5.98 \pm 0.632$ & $5.72 \pm 0.631$ & $4.92 \pm 0.731$ & $6.01 \pm 0.610$ \\
\hline Nitrite-nitrogen $(\mu \mathrm{mol} / \mathrm{l})$ & $0.211 \pm 0.018$ & $0.182 \pm 0.016$ & $0.202 \pm 0.022$ & $0.198 \pm 0.022$ & $0.21 \pm 0.003$ & $0.23 \pm 0.061$ \\
\hline Nitrate-nitrogen $(\mu \mathrm{mol} / \mathrm{l})$ & $0.31 \pm 0.086$ & $0.23 \pm 0.014$ & $0.28 \pm 0.136$ & $0.33 \pm 0.046$ & $0.28 \pm 0.029$ & $0.31 \pm 0.14$ \\
\hline
\end{tabular}


Citation: Anila Kumary KS (2016) Temporal Variations in the Distribution of Interstitial Meiofauna along the Southwest Coast of India. J Climatol Weather Forecasting 4: 178. doi:10.4172/2332-2594.1000178

Page 3 of 4

\begin{tabular}{|l|l|l|l|l|l|l|}
\hline $\begin{array}{l}\text { Phosphate-phosphorus } \\
(\mu \mathrm{mol} / \mathrm{l})\end{array}$ & $0.21 \pm 0.07$ & $0.161 \pm 0.072$ & $0.27 \pm 0.056$ & $0.28 \pm 0.008$ & $0.21 \pm 0.013$ & $0.29 \pm 0.017$ \\
\hline Silicate-silicon $(\mu \mathrm{mol} / \mathrm{l})$ & $0.23 \pm 0.03$ & $0.106 \pm 0.008$ & $0.181 \pm 0.06$ & $0.21 \pm 0.061$ & $0.091 \pm 0.007$ & $0.198 \pm 0.012$ \\
\hline
\end{tabular}

Table 2: Temporal variations (mean) in hydrological variables along Thiruvananthapuram coast, Kerala.

\begin{tabular}{|l|l|l|l|l|l|l|}
\hline \multirow{2}{*}{ Parameter } & \multicolumn{2}{|l}{ Poonthura coast } & \multicolumn{2}{l|}{ Adimalathura coast } \\
\cline { 2 - 7 } & Pre monsoon & Monsoon & Post monsoon & Pre monsoon & Monsoon & Post monsoon \\
\hline Temperature $\left({ }^{\circ} \mathrm{C}\right)$ & $30.00 \pm 0.61$ & $25.10 \pm 0.88$ & $29.10 \pm 0.58$ & $29.70 \pm 0.701$ & $24.2 \pm 0.515$ & $29.50 \pm 0.412$ \\
\hline Organic carbon $(\%)$ & $0.31 \pm 0.28$ & $0.23 \pm 015$ & $0.56 \pm 0.13$ & $0.70 \pm 0.14$ & $0.45 \pm 0.09$ & $0.64 \pm 0.09$ \\
\hline Sand $(\%)$ & $77.76 \pm 5.03$ & $96.45 \pm 3.65$ & $96.62 \pm 4.32$ & $73.61 \pm 3.12$ & $98.75 \pm 1.01$ & $84.86 \pm 6.15$ \\
\hline Silt (\%) & $14.16 \pm 2.92$ & $2.76 \pm 1.22$ & $1.33 \pm 0.92$ & $16.1 \pm 4.46$ & $0.62 \pm 03$ & $3.51 \pm 1.25$ \\
\hline Clay (\%) & $8.08 \pm 3.30$ & $0.79 \pm 0.63$ & $2.05 \pm 1.16$ & $10.29 \pm 3.50$ & $0.62 \pm 0.03$ & $11.63 \pm 1.25$ \\
\hline
\end{tabular}

Table 3: Temporal variations (mean) in geological parameters along Thiruvananthapuram coast, Kerala.

Vertically, the majority of meiobenthic organisms are confined to the upper $10 \mathrm{~cm}$ depth (Figure 3). Mostly nematodes are found to penetrate the deep layers and found in the entire $25 \mathrm{~cm}$ depth. Foraminifera are the other group in the deeper layers of the sediment. $21 \%$ of foraminifera and $25 \%$ nematoda penetrate the deeper (more than $10 \mathrm{~cm}$ ) layer. Of all the other groups only oligochaeta and archiannelida were recorded from the deepest $(20-25 \mathrm{~cm})$ layer. Decrease in faunal density in the deeper layers has been attributed to the reduction in interstitial space, oxygen content and food material [29]. One of the reasons for the successful penetration of nematodes into deeper layers could be attributed to their capacity of anaerobic existence [1]. Seasonal variations were evident in the vertical distribution meiobenthos with highest density in the surface section $(0-5 \mathrm{~cm})$ during the monsoon period at both the beaches and maximum density in the 5-10 cm layer during other seasons (Figures 4 and 5). Meiofauna in sandy sediments generally appear to be concentrated at those levels where desiccation is not too severe and oxygen availability is not too low [30,31]. Because of better drainage of sand and higher temperature at the surface layer the fauna found penetrated to the deeper layer during pre and post monsoon seasons.

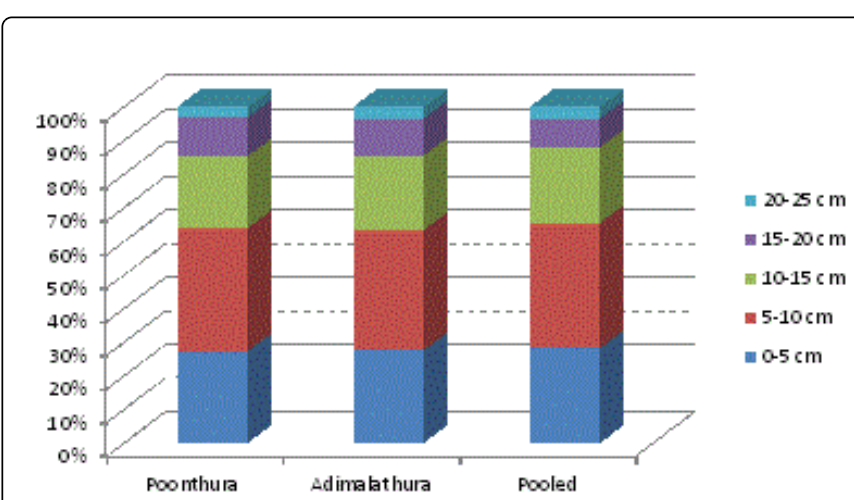

Figure 3: Vertical distribution of meiofauna (annual\%) along Thiruvananthapuram coast.

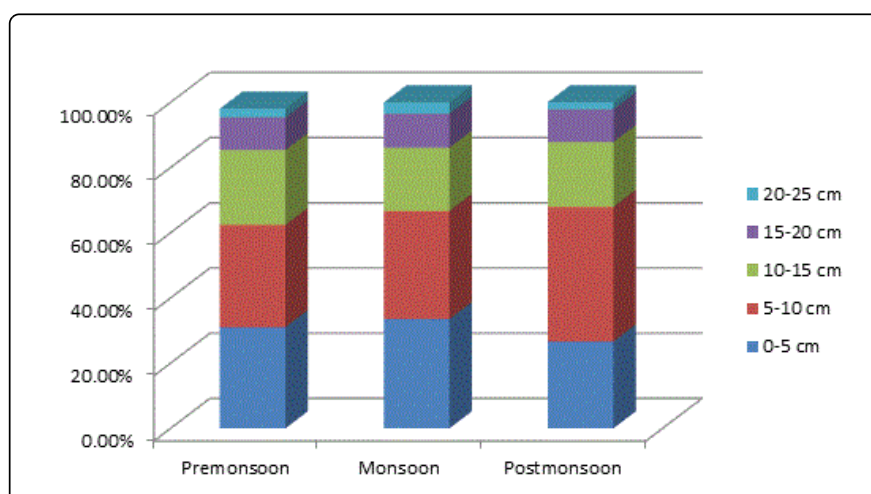

Figure 4: Seasonal variation in the vertical distribution of meiofauna (Poonthura coast).

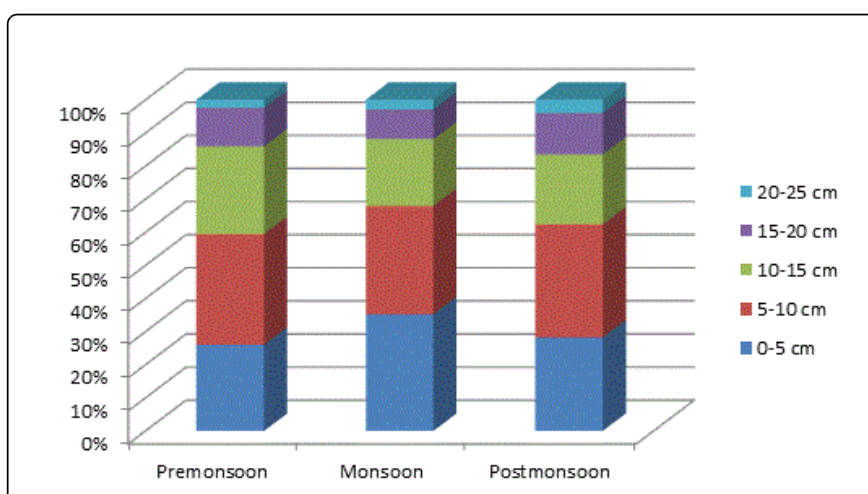

Figure 5: Seasonal variations in the vertical distribution of meiofauna (Adimalathura coast).

The study revealed distinct seasonal variation in interstitial meiobenthos along the coast of Thiruvananthapuram, Kerala on the southwest coast of India. The meiobenthic abundance in general was 
found in accordance with sediment granulometry and physicochemical characteristics of water prevailing along the coast. Temperature, $\mathrm{pH}$, salinity, dissolved oxygen, sediment composition and $\%$ of organic carbon in the sediment are proved to be important descriptive parameters related to the abundance and distribution of meiobenthos. Different meiofaunal components showed difference in vertical movement. A downward migration of meiofauna has been observed in the study area due to better drainage, high temperature and exposure.

\section{References}

1. Damodaran R (1973) Studies on the benthos of the mud banks of the Kerala coast. Bull Dept Mar Sci univ Cochin pp: 1-126.

2. Ansari ZA, Parulekar AH, Jaytap TG (1980) Distribution of sublittoral meiobenthos of Goa coast, India. Hydrobiologia 74: 209-214.

3. Ansari ZA, Chatterji A, Parulekar AH (1984) Effect of domestic sewage on sand beach meiofauna at Goa, India. Hydrobiologia 111: 229-233.

4. Ingole BS, Ansari ZA, Parulekar AH (1987) Meiobenthos of Saphala salt marsh, west coast of India. Indian J Mar Sci 16: 110-113.

5. Sajan S, Damodaran R (2007) Faunal composition of meiobenthos from the shelf regions off the west coast of India. J Mar Biol Ass India 49: 19-26.

6. Sajan S, Joydas TV, Damodaran R (2010) Meiofauna of the western continental shelf of India, Arabian Sea. Estuar Coast Shelf Sci 86 665-674.

7. Priyalakshmi G, Menon NR (2014) Ecology of interstitial faunal assemblages from the beaches along the coast of Kerala, India. Int J Oceanogr pp: 1-9.

8. Sinu J Varghese, Miranda MTP (2015) Meiobenthic diversity and abundance along Arthunkal coast in Kerala, southwest coast of India. J Mar Biol Ass India 57: 78-83.

9. Wieser W (1960) Benthic studies in Buzzards Bay II. The meiofauna. Limnol Oceanogr 5: 121-137.

10. Strickland JDH, Parsons TR (1972) A manual for sea water analysis (2nd edn.) Bull Fish Res Brd Canada 167: 310.

11. Grasshoff K, Ehrhartt M, Kremling K (1983) Methods of sea water analysis, Verlag, Chemic Germany p: 419.

12. Krumbein WC, Pettijohn FJ (1938) Manual of sedimentary petrography, Appleton-Century Crafts, NewYork p: 549.

13. Ansari ZA, Prita Ramani C, Rivonker V, Parulekarv AH (1990) Macro and meiofaunal abundance in six sandy beaches of Lakshadweep islands. Indian J Mar Sci 19: 159-164.

14. Rao DG (1987) Ecology of meiobenthos of Rambha bay in Chilka lagoon J Mar Biol Ass India 29: 74-85.

15. Ansari ZA, Parulekar AH (1994) Meiobenthos in the sediments of sea grass meadows of Lakshadweep atoll, Arabian sea. Vie Milieu 44: 185-190.
16. Sarma ALN, Wilsand V (1994) Littoral meiofauna of Bhitarkanika mangrove of Mahanadi system, East coast of India. Indian J Mar Sci 23: 221-224.

17. Ansari KGM, Lyla TPSI, Ajmalkhan S (2012) Faunal composition of metazoan meiofauna from the south east continental shelf of India. Indian J Geo-Marine Sci 41: 457-467.

18. Anupama C, Srinivasa Rao M, Vijaya Bhanu CH (2015) Distribution of meiobenthos off Kakinada Bay, Gaderu and Coringa estuarine complex. J Mar Biol Ass India 57: 17-26.

19. Anita Patnaik, Rao MVL (1990) Composition and distribution of interstitial meiofauna in the sandy beaches of Gopalpur, south Orissa coast. Indian J Mar Sci 19: 165-170.

20. Suresh K, Shafiq Ahamed M, Durairaj G (1992) Ecology of interstitial meiofauna at Kalpakkam coast, east coast of India. Indian J Mar Sci 21: 217-219.

21. Harris RP (1972) Seasonal changes in population density and vertical distribution of harpacticoid copepod on an intertidal sandy beach. J Mar Biol Ass UK 52: 493-505.

22. Sarma ALN, Ganapati PN (1975) Meiofauna of the Visakhapatnam harbor in relation to pollution. Bull Dept Mar Sci Cochin 7: 243-255.

23. Sarma NSR, Mohan PC (1981) On the ecology of interstitial fauna inhabiting the Bhimilipatnam coast (Bay of Bengal). Mahasagar-Bull Natn Inst Oceanogr 14: 257-263.

24. Harkantra SN, Parulekar AH (1989) Population distribution of meiofauna in relation to some environmental features in a sandy intertidal region of Goa, west coast of India. Indian J Mar Sci 18: 202-206.

25. Palacin C, Martin D, Gile JM (1991) Features of spatial distribution of benthic infauna in a Medeterranian shallow water bay. Mar Biol 100: 315-321.

26. Somerfield JDH, Gee JM, Warwick RM (1994) Soft sediment meiofaunal community structure in relation to a long heavy metal gradient in the Fal estuarine system. Mar Ecol Prog Ser 105: 79-88.

27. Ansari ZA, Mehta P, Furtado R, Aung C, Pandiarajan RS (2014) Quantitative distribution of meiobenthos in the gulf of Martaban, Myanmar Coast, North east Andaman sea. Indian J Geomarine Sci 43: 189-197.

28. Rao KK, Sivadas P, Narayanan B, Jayalakshmi KV, Krishnankutty M (1987) Distribution of foraminifera in the lagoons of certain islands of the Lakshadweep Archipelago, Arabian sea. Indian J Mar Sci 16: 161-178.

29. McIntyre AD (1969) Ecology of marine meiobenthos. Biol Rev 44: 245-290.

30. McLachlan AP, Winter ED, Bhota L (1977) Vertical and horizontal distribution of sublittoral meiofauna in Algoa bay, South Africa. Mar Biol 40: 355-364.

31. Fernando OJ (1987) Studies on the intertidal fauna of the Vellar estuary. J Mar Biol Ass India 29: 86-103. 